\title{
Russlands rebeller: Protest og reaksjon i Putins Russland (2011-2020)
}

\author{
Geir Flikke \\ Oslo: Cappelen Damm Akademisk 2020 \\ 257 sider. ISBN: 9788202678944
}

Omtalt av Anni Roth Hjermann [rådgiver ved Norsk utenrikspolitisk institutt (NUPI), annirh@nupi.no]

Boken Russlands rebeller av professor Geir Flikke utkom høsten 2020 med en nærmest profetisk timing. Den dramatiske forgiftningen av bokens hovedperson, den prominente Putin-kritikeren Aleksej Navalnyj, skjedde 20. august - akkurat tidsnok til å nevnes i forordet. I etterkant har historien om Navalnyj nådd et foreløpig klimaks. Da Navalnyj returnerte til Russland fra sykehusoppholdet i Berlin 17. januar 2021, ble han umiddelbart arrestert. Kort tid etter ble filmen «Putins palass» sluppet til skyhøye seertall på YouTube, der Navalnyj hevder at Putin er eieren av en overdådig eiendom ved Svartehavet. Arrestasjonen og filmen utløste store gateprotester over hele Russland den 23. januar, 31. januar og 2. februar, sistnevnte etter at Navalnyj ble idømt 3,5 år i fengsel. Til sammen ble over 11000 anholdt i disse demonstrasjonene (ifølge monitoreringsnettstedet OVD-info). Mange rapporterte om politivold, men Navalnyjs støttespillere lovet å holde stand. Legg til at Navalnyj-saken har ført til ytterligere spenninger mellom Russland og Vesten, og det blir tydelig at den som vil forstå russisk politikk bør studere historien om Russlands rebeller. Rustet med bunnsolid språk- og områdeforståelse samt sosial bevegelsesteori tar Flikke oss tilbake til begynnelsen, og går i dybden på oppturene og nedturene i denne David-mot-Goliataktige sagaen. Samtidig dokumenterer boken utviklingen av Russlands stadig mer omfattende og sofistikerte undertrykkelsesapparat.

Strukturen er oversiktlig og kronologisk basert. Etter et første teorikapittel følger seks empiriske kapitler. Disse utgjør en tidslinje over de viktigste hendelsene i den lange protestsyklusen fra 2011 til 2019: startskuddet med gateprotestene i 2011/2012 (kapittel 2), påfølgende organisering av opposisjonen og forsøk på koordinering og koalisjonsbygging (kapittel 3), valgkampen i regionene i 2015 (kapittel 4), mobilisering til Duma-valget i 2016 og koalisjonens kollaps (kapittel 5), store gateprotester og Navalnyjs presidentkampanje i 2018 (kapittel 6) og protestene knyttet til arrestasjonen av journalisten Golunov og byrådsvalg i Moskva i 2019 (kapittel 7). Kapittel 8 sammenfatter, konkluderer og trekker inn nyere utvikling, som grunnlovsendringene fra 
2020. Boken viser hvordan protestbevegelsen og en stadig bredere vifte av statlige kontrollmekanismer vokser frem parallelt, hvilket illustrerer den overordnede dynamikken mellom protest og reaksjon godt. Det er verdt å merke seg hvordan opposisjonen har strukturert sine aktiviteter rundt valg på ulike nivåer (lokalt, regionalt og nasjonalt) nesten hvert år fra 2011-2019 (se s. 228). Selv om vinnersjansene aldri var reelle, kan også ufrie og urettferdige valg være arenaer for en bredere mobilisering.

Navalnyj er helt sentral i denne empirisk rike beretningen, men bokens fulle persongalleri er nesten som i en Tolstoj-roman. Det blir tidvis noe uoversiktlig, selv for den Russlands-interesserte leser, når aktører, steder, medier, datoer, aksjoner og lover presenteres i et forrykende tempo. Samtidig gjør detaljrikdommen, hjulpet av Flikkes sterke språkføring, at boken blir svært levende, og leseren kastes rett inn i begivenhetenes sentrum. Flikkes kildebruk demonstrerer at i internettets tidsalder er «tykke beskrivelser» mulige også uten feltarbeid. Boken bygger på omfattende russiskspråklige kilder, med hovedvekt på liberale nyhetsmedier, sosiale medier og i noen grad regimevennlige medier (s. 37-38), men jeg savner en kort drøfting av ulemper eller skjevheter knyttet til kildeutvalget.

Flikkes krønike om Russlands rebeller lener seg på sosial bevegelsesteori (SMT), og følgelig er søkelyset rettet mot budskap, taktikker og enkeltaktøren Navalnyj (innramminger, repertoarer og protestbiografier i bokens terminologi). De abstrakte teoretiske kategoriene presentert i kapittel én får saftig empirisk kjøtt på beinet i resten av boken. På troverdig vis demonstrerer forfatteren hvordan protestbevegelsen har vokst gjennom en kombinasjon av flere faktorer: dokumentasjon på og motstand mot maktelitens korrupsjon, innovativ bruk av informasjonsteknologi og fingerspitzgefühl for sosiale medier, organisering av frivillige, prioritering av gateprotester samt Navalnyjs personlige og ideologiske (populistiske) appell. Slik understøtter Navalnyjs metode at internett er en ny type mulighetsstruktur for protestbevegelser, som foreslått i teoridelen (s. 35). Personlig satte jeg spesielt pris på de mange eksemplene på bevegelsens bruk av humor, særlig ironi, levende gjengitt via raus bruk av sitater, samt fotografier. Her kommer Flikkes stålkontroll på den russiske politiske konteksten til sin fulle rett, for eksempel når han viser hvilke Medvedev-sitater demonstrantene harselerer med (s. 190, s. 194).

Samtidig diskuterer Flikke flere forhold som det teoretiske rammeverket ikke favner om eller ikke anvendes på. Dette gjelder særlig forhold som virker i protestbevegelsens disfavør og som derfor kan svare på puzzlet Flikke antyder innledningsvis (s. 24): Hvorfor ble ikke de store protestene i 2011-2012 starten på en ny demokratibølge i Russland? To forklaringer boka drøfter, er splittelser og samarbeidsproblemer innad i opposisjonen og det stigmatiserende narrativet dyrket frem av Kreml om at Navalnyj representerer en vestligsponset femtekolonne à la (Kremls syn på) Maidanbevegelsen i Ukraina. Flikke ansporer til en teoretisk forklaring av sistnevnte når han kaller femtekolonnenarrativet en "motinnramming» fra regimet (s. 64), men dette analytiske grepet følges ikke opp i den videre analysen, selv om temaet kommer opp flere ganger (bl.a. s. 103, s. 150, s. 166). Gitt at Flikke endog trekker det inn i 
konklusjonen (s. 238), savner jeg en mer systematisk analytisk tilnærming til Kreml og assosierte aktørers forsøk på å koble bevegelsen til Vesten/Maidan.

Det ligger et uutnyttet potensial i det som fremstår som et viktig bidrag til sosial bevegelsesteori, nemlig Flikkes typologi på s. 37 over regimerepertoarer (preskriptive, selektive, involverende og nøytraliserende) og motsvarende protestrepertoarer. For eksempel viser den at sosiale bevegelser kan svare på nøytraliserende undertrykkelsespolitikk, som struper ressurser for eksempel gjennom avvikling av NGO-er, med crowdfunding og organisering av frivillige. Jeg savner en tydelig redegiørelse for hvordan Flikke har utviklet typologien, men den fremstår som en fruktbar analytisk ramme for bokens hovedformål, nemlig å gripe vekselvirkningen mellom protest og reaksjon i Russland. Slik bygger den også bro mellom litteraturen om sosiale bevegelser og litteraturen om hybride og autoritære regimer. Empirisk sett lykkes Flikke godt med å vise at det russiske autoritære regimet er dynamisk og læredyktig i møte med utfordringene fra protestbevegelsen, og hvis han hadde engasjert empirien systematisk med typologien, kunne resultatet blitt et rammeverk med analytisk nytte også utenfor det postsovjetiske området.

Totalt sett er dette en imponerende rik fremstilling om en protestbevegelse vi ennå ikke har sett slutten på. Flikkes bok er en verdifull ressurs for å forstå hvor bevegelsen kommer fra og hvilke suksesser og tilbakeskritt den har opplevd siden startskuddet i 2011. Mye er endret, men det er også kontinuitet - i 2021, som i 2012, (s. 49) er "her er det vi som har makten" (my zdes vlast) et viktig slagord. Boken tilbyr også empirisk mat for alle som er interessert $\mathrm{i}$ teoriutvikling om protest og reaksjon $\mathrm{i}$ autoritære regimer. Hvis man holder tunga rett i munnen i møte med alle detaljene, er den dessuten noe av en pageturner. 